\title{
Coeliac disease in China, a field waiting for exploration
}

\author{
J. Wu ${ }^{1}$, B. Xia ${ }^{2}$, B. M.E. von Blomberg ${ }^{3}$, C. Zhao $^{4}$, X. W. Yang ${ }^{4}$, J. B. A. Crusius ${ }^{5}$ and A. S. Peña ${ }^{5}$ \\ ${ }^{\prime}$ Gastroenterology Department. Jiangsu Provincial Hospital of Traditional Chinese Medicine (TCM). Nanjing, Jiangsu \\ Province. China. ${ }^{2}$ Gastroenterology Department and Research Centre of Digestive Diseases. Zhongnan Hospital of \\ Wuhan University. Wuhan, China. ${ }^{3}$ Medical Immunology. Department of Pathology. VU University Medical Center. \\ Amsterdam, The Netherlands. ${ }^{4}$ Clinical Laboratory. Jiangsu Provincial Hospital of TCM. Jiangsu Province, China. \\ ${ }^{5}$ Laboratory of Immunogenetics. Department of Pathology. VU University Medical Center. Amsterdam, The Netherlands
}

\begin{abstract}
Background: no systematic studies on the prevalence of coeliac disease $(\mathrm{CD})$ have been reported from China. In western populations $\mathrm{CD}$ is more common in patients with insulin dependent diabetes mellitus (IDDM) and in diarrhoea-predominant irritable bowel syndrome (D-IBS). We have screened patients with these conditions presenting to the outpatient department of a large hospital of "Traditional Chinese Medicine" (TCM) in Nanjing, Jiangsu province, P.R. China.

Methods: we tested sera of 78 unrelated Han Chinese patients (5 IDDM and 73 D-IBS), using ELISA serological tests for IgG anti-gliadin antibodies (IgG-AGA) and IgA anti-tissue transglutaminase antibodies (IgA-tTG).

Results: six out of 78 patients (7.7\%) were positive for IgGAGA (two men and four women) and two (2.6\%) were positive for IgA-tTGs. One of the latter patients was negative for IgG-AGA. Besides, one patient had a dubious IgA-tTG antibody and a positive IgG-AGA. None of the six patients agreed to undergo duodenal biopsy. Two out of these six patients followed a gluten-free diet for one year. In one patient the diarrhoea ceased and his body weight increased. Another stopped losing weight.

Conclusions: this study previously published as a letter in GUT (Wu J, Xia B, von Blomberg BME, Zhao C, Yang XW, Crusius JBA, Peña AS. Coeliac disease: emerging in China? Gut 2010; 59(3): 418-9) demonstrated that CD may exist in the Jiangsu province of P.R. China. The present article draws attention to the difficulties of following a standard protocol in China such as established in western countries and highlights important factors less well known in the west in relation to the development of $\mathrm{CD}$ in China. Wheat production became significant in China between 1600 and 1300 B.C. After the Han dynasty (500-200 B.C.), wheat was one of the main cereals in China. One the major wheat fields in China is located in the Jiangsu province where the research for this article was performed. A review of Chinese literature shows that the predominant HLA-DQ CD risk alleles and haplotypes are present in the Jiangsu province. Genetic background, food consumption, and the results of our study suggest that CD should actively be investigated in P.R. China.
\end{abstract}

Key words: Coeliac disease. China. Anti-gliadin antibody. Tissue transglutaminase antibody. HLA-DQ2. HLA-DQ8. Wheat consumption.

Received: 01-02-10.

Accepted: 16-02-10.

Correspondence: Prof A.S. Peña. Laboratory of Immunogenetics. Department of Pathology. VU University Medical Center. PO Box 7057. 1007 MB Amsterdam, the Netherlands.e-mail: pena.as@gmail.com
Wu J, Xia B, von Blomberg BME, Zhao C, Yang XW, Crusius $J B A$ and Peña S. Coeliac disease in china, a field waiting for exploration. Rev Esp Enferm Dig 2010; 102: 472-477.

\section{INTRODUCTION}

Coeliac disease (CD), the most common food sensitive enteropathy in humans, is an intolerance to dietary gluten (wheat, barley, rye, and possibly some varieties of oats) as well as environmental factors are necessary for the initiation of the disease. $\mathrm{CD}$ is considered to be primarily a $\mathrm{T}$ cell mediated disease and occurs in genetically predisposed individuals. The majority of patients express the HLA-DQ2 [encoded by alleles HLA-DQA $1 * 0501$, DQB1*02], and/or HLA-DQ8 [DQA1*03, DQB1*0302] molecules. Gluten specific HLA-DQ restricted $\mathrm{T}$ cells are present at the site of the lesion in the gut. A glutenfree diet (GFD) brings the disease process in remission (1). CD can affect persons of many ethnic backgrounds, including people from Middle Eastern and North African countries (2) but appears to rarely affect people of African-Caribbean, Chinese, or Japanese descent. To find if CD exists in China, we started to screen for this disease by means of serological tests, in high risk populations such as patients suffering from insulin dependent diabetes mellitus (IDDM) and diarrhoea-predominant irritable bowel syndrome (D-IBS).

It is known in the west that between 4 and $9 \%$ of patients with IDDM suffer from CD (3-10). Also, there is an increased prevalence of patients with IDDM and hypothyroidism in $\mathrm{CD}$ (8-11). The cause of the association of IDDM with CD is not fully known, although the common risk is related to the haplotypes HLA-DR3-HLADQ2 and HLA-DR4-HLA-DQ8, which contribute to the susceptibility to IDDM or to CD. Lie et al. have suggested that a gene(s) in the vicinity of the microsatellite D6S2223 on HLA-DR3 haplotypes is involved in the pathogenesis of both of these immune-mediated diseases (12). Although the prevalence of IDDM in China is lower than in Caucasians, the sharing of IDDM and CD genes 
suggests that Chinese IDDM patients may have the same high risk to suffer from CD similar to the risk in the west (13-15).

Individuals with gastrointestinal symptoms, including chronic diarrhoea, malabsorption, weight loss, and abdominal distension, should be tested for CD $(16,17)$. In a prospective study, Sanders et al., found that compared with matched controls, irritable bowel syndrome was significantly associated with CD (18). This observation has been confirmed in several studies (19-22). CD is common in patients with IBS (23). In a meta-analysis of cases which comply with diagnostic criteria of IBS, the prevalence of biopsy-proved CD was more than 4-fold higher than in a control group (19). D-IBS is the most common form of presentation in the Western world (24). In China, chronic diarrhoea and D-IBS are two of the usual presentations to gastrointestinal disease clinics. Therefore, patients suffering from D-IBS were also enrolled in our project.

\section{PATIENTS}

Seventy-eight patients from Jiangsu province, 5 IDDM patients and 73 D-IBS patients (30 F/48 M), mean age 50 ( \pm 15 years), fulfilling the ROME II criteria (25-27), were included in the study. The patients are Han Chinese and unrelated. All consumed wheat products in their diet.

\section{Serological tests}

All serum samples were collected from the patients at Jiangsu Provincial Hospital of TCM between December 2002 and August 2005. Samples were stored at $-80{ }^{\circ} \mathrm{C}$ until analysis. IgA anti-tissue transglutaminase (IgAtTG) antibodies were measured by ELISA (IgA-tTG, Sigma T5398/lot 99H7425) (28). The antibody content of the sera was calculated in DU/ml using a standard curve and values above $8 \mathrm{DU} / \mathrm{ml}$ were considered positive for IgA-tTG antibodies. IgG anti-gliadin antibody (IgGAGA) was measured with the assay (BL Diagnostika, Germany, 5B34LG/lot40950) according to the manufacturer's instructions. The antibody content of the sera was calculated in $\mathrm{U} / \mathrm{ml}$ using a standard curve. Values above $10 \mathrm{U} / \mathrm{ml}$ were considered positive for IgG anti-gliadin antibodies. Total serum IgA was measured to exclude $\operatorname{IgA}$ deficiency. The patients gave written informed consent for serological testing.

\section{RESULTS}

Six out of 78 patients $(7.7 \%)$ were positive for IgGAGA (4F/2M). Two out of 78 patients (2.6\%) were positive for $\operatorname{IgA-tTG}$ and one of these two was negative for
IgG-IgA antibody. Besides this, one patient had a dubious IgA anti-tTG antibody and a positive IgG-AGA (Table I).

Table I. Seven positive cases identified by serological tests out of 78 patients

\begin{tabular}{lcccc}
\hline Case & Gender & Age in years & $\begin{array}{c}\text { IgG-AGA } \\
(\mathrm{U} / \mathrm{ml})\end{array}$ & $\begin{array}{c}\text { IgA-tTG } \\
(\mathrm{U} / \mathrm{m} /)\end{array}$ \\
\hline Case 1 & Male & 64 & 27.6 & Negative \\
Case 2 & Female & 20 & 30.3 & Negative \\
Case 3 & Male & 20 & 50.1 & Negative \\
Case 4 (IDDM) & Female & 37 & 28.8 & Negative \\
Case 5 & Female & 55 & 12.2 & Negative \\
Case 6 & Female & 64 & 26.7 & 9.6 \\
Case 7 & Male & 26 & Negative & 8.6 \\
Positive control & Not known & Not known & 69.5 & 50.9 \\
\hline IgG-AGA: immunoglobulin G antigliadin antibody; CD: coeliac disease; IDDM: insulin-depen-
\end{tabular}

dent diabetes mellitus; IgA-tTG: IgA-anti-tissue transglutaminase antibody.

\section{Follow-up}

We explained to all the patients the possible role of gluten in $\mathrm{CD}$ and the necessity for CD patients to follow a strict GFD and that only a small bowel biopsy confirms the diagnosis. They indicated to have considered this but preferred to follow a GFD without undergoing a duodenal biopsy or capsule endoscopy. We respected their decision and did not persist. Two persons followed a GFD for a year. Diarrhoea stopped. A young man (case 3 of table I) gained weight and one woman (case 5 of table I) stopped losing weight.

Although it is easy for Chinese people to switch to a GFD since rice is another leading cereal in China, only two patients accepted to follow a GFD.

\section{DISCUSSION}

In our research, 7 out of 78 patients with high risk to suffer from CD were IgA-tTG and/or IgG-AGA positive. Only two patients accepted to follow a GFD. Both showed clinical improvement. The limitation of this study is the absence of duodenal biopsy data. Efforts are being made to improve this shortcoming in our screening procedures.

In China, physicians and pediatricians are not familiar with CD. There are some reviews published in Chinese journals but they refer to Chinese patients living outside China. Sun et al., reported a Chinese child with CD (Chinese Journal of Lab Medicine 2008; 31(6): 713-6). Jiang et al. investigated by capsule endoscopy (June 2003-March 2008) 62 patients with chronic diarrhoea and weight loss. They diagnosed CD in four patients. A GFD significantly improved the clinical condition of all four patients (29). 
The consumption of wheat products at present is not comparable to the consumption of rice however it is increasing (Table II) -The Nutrition and Health Status of the Chinese People. 12/10/04. Ministry of Health of People's Republic of China, Ministry of Science and Technology of the People's Republic of China, National Bureau of Statistics. In Chinese, available at:

http://news.xinhuanet.com/video/2004-10/12/content_2080855.htm)-.

In a recent report from the Nuffield Australia Farming Scholars (Project No. 0908) Leon Ryan has extensively written on grain demand and consumption trends in the Chinese, Indian and Durum wheat markets. He describes the changes in dietary habits in China. China is the world's largest producer of wheat, accounting for almost $20 \%$ of the global production. In English, available at:

http://www.nuffield.com.au/schols_f/win_f/ryan.html).

Dr. Joseph Murray, a leading US gastroenterologist and expert in CD lectured at the Tri-County Celiac Sprue Support Group (TCCSSG) in October 1996: -"CD is rare in the Negroid and Asian races, though not unheard of. This may be because the major starch in China and Africa was not wheat until fairly recently. So until these populations are exposed to large amounts of wheat, we may not know what the true prevalence of $C D$ is in those countries." Available at:

http://www.enabling.org/ia/celiac/spectrum.html).

Nevertheless, as mentioned in the introduction, wheat has been in China for at least four thousand years. According to archaeological findings, in the north of China, wheat became a significant crop between 1600 and 1300 B.C. (30). China was a world agricultural centre covering both southern and northern areas. After the Han dynasty (500-200 B.C.), wheat was one of the main foods in China. It keeps a dominant position in the north of China. Since the North Song dynasty (960 A.D.-127 A.D.), wheat was also introduced in southern parts of China (31). At present, Chinese people consume various kinds of wheat products, e.g. noodles, steamed bread, and dumplings. The Chinese have a long history of consuming "mianjin" or "kaofu", which are basically gluten products. Wheat is the second leading cereal in China in terms of both harvested area and production. More than $90 \%$ of wheat grain is used to make steamed bread and noodles. Although wheat is grown in 29 of 30 Chinese provinces, more than $90 \%$ is produced in 13 provinces; of these Shandong, Henan, Jiangsu, Hebei, and Anhui contribute more than $60 \%$ of the total production (32). See figure 1 for wheat production in China or see the link:

http://www.iiasa.ac.at/collections/IIASA_Research/S RD/ChinaFood/data/maps/crops/wheat_h.htm

Jiangsu province is located in the east of China along the Yangtze River. Chinese agriculture is also progressing into a new era whereby gluten content in wheat is now much higher than before. - "Over the last 200 years active programmes in genetic selection and manipulation have changed the character of the original Triticacee from few grains and low gluten to abundant grains rich in gluten forming proteins":

http://www.fao.org/docrep/x2184e/x2184e03.htm

Could the genetic background, particularly the frequency of HLA-DQ2 and/or HLA-DQ8 be the main explanation for the prevalence of CD? The value and the accuracy of serologic tests and HLA-DQ typing for diagnosing $\mathrm{CD}$ has been defined in a prospective study in the Netherlands (33). Since China is a multiracial country, the distribution of HLA-DQ differed in different ar-

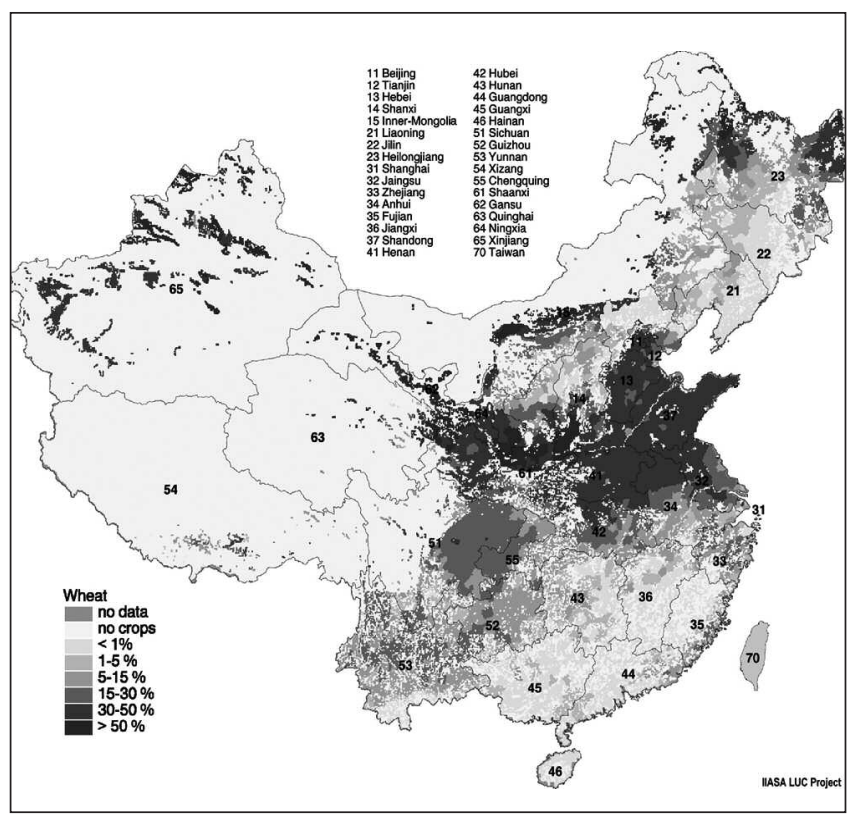

Fig. 1. This map displays the cultivation intensity of wheat in China.

Table II. Food intake of national residents in 1982, 1992, 2002 (grams/standard person/day)

\begin{tabular}{|c|c|c|c|c|c|c|c|c|c|}
\hline & \multicolumn{3}{|c|}{ Total } & \multicolumn{3}{|c|}{ Urban } & \multicolumn{3}{|c|}{ Rural } \\
\hline & 1982 & 1992 & 2002 & 1982 & 1992 & 2002 & 1982 & 1992 & 2002 \\
\hline Rice and products & 217 & 226.7 & 239.9 & 217 & 223.1 & 217.8 & 217 & 255.8 & 248.4 \\
\hline Other cereals & 103.5 & 34.5 & 23.3 & 24 & 17 & 16.3 & 137 & 40.9 & 25.9 \\
\hline Potatoes & 179.9 & 86.6 & 49.5 & 66 & 46 & 31.9 & 228 & 108 & 56.2 \\
\hline
\end{tabular}

Standard person $=18$ years old, light work man (from The Nutrition and Health Status of the Chinese People.12/10/04). 
eas. The frequency of the MHC class II haplotype HLA-DRB $1 * 0301-D Q A 1 * 05-D Q B 1 * 02$ is high in northern China along the Silk Route, where the consumption of wheat is higher than in the south. The risk to suffer from CD may thus be higher too. In the Jiangsu Province, the province of our research, the allele frequency of HLA-DQB $1 * 0201 / 02$ is $17.8 \%$ and of HLADQB $1 * 0302,5.6 \%$. The haplotype frequency of HLA-DQA $1 * 0501-D Q B 1 * 0201 / 02$ (HLA-DQ2) is $7.2 \%$ and the haplotype frequency of HLADQA $1 * 0301 / 02 / 03-H L A-D Q B 1 * 0302$ (HLA-DQ8), $4.7 \%$ (34). The Han Chinese have traditionally been geographically divided by the Yangtze River into two parts, northern Han Chinese and southern Han Chinese and this may influence the distribution and frequency of HLA and other immunoregulatory genes (35).

Only a small part of the HLA-DQ2 positive Caucasian population suffers from $\mathrm{CD}$. The contribution of the HLA region to the development of CD among siblings is about $40 \%$ (36). The concordance for the disease is about $75 \%$ in identical twins and only $11 \%$ in non-identical twins. Our current knowledge does not explain why only a small percentage of HLA-DQ2 and DQ8 positive individuals develop the disease. Recent genome-wide association studies and non-synonymous SNP scans have identified new genes that may explain the genetic basis of the shared pathogenesis of immunerelated diseases, e.g. the genes IL2/IL21, SH2B3, and IL18RAP may explain the previously mentioned association of CD with IDDM, the gene TNFAIP3 may explain an association of $\mathrm{CD}$ with systemic lupus erythematosus and rheumatoid arthritis (37). It is known that the HLA-DR3-DQ2 haplotype is present in many other associated diseases of autoimmune origin. We still do not know whether there are protective genes playing a role in disease expression.

$\mathrm{CD}$ is a heterogeneous disease. Due to the protean manifestations of the disease and the often mild but indolent course, the diagnosis is often missed and even in European countries such as in Spain, the atypical forms of the disease are difficult to diagnose (38-41). Current methods to diagnose the unresponsive and complicated forms of CD have been recently reviewed $(42,43)$.

The efforts to increase awareness of $\mathrm{CD}$ is justified since undiagnosed $\mathrm{CD}$ is associated with a nearly 4 -fold increased risk of death (44). A modest but significant increased risk of death among patients with $\mathrm{CD}$, inflammation, or latent CD has been documented in Sweden (45).

As we have reviewed in this article, gene background, wheat consumption and our findings justify an active pursue of $\mathrm{CD}$ in China. The histological diagnosis of $\mathrm{CD}$ is considered the gold standard, but this method is not free of potential problems such as the failure to make a correct assessment when biopsy specimens have been poorly orientated or tangentially cut (46). The method of histological assessment is also very relevant (47). To improve the diagnostic yield it is important that endo- scopists orient the biopsy specimens before fixing the samples. A fine brush helps to handle the specimens and at least 4 specimens should be taken to maximize diagnostic accuracy.

Recent work has provided evidence that the intestinal flora of patients with $\mathrm{CD}$ differs from healthy control (48-50). This finding may turn out to be of relevance to understand the pathogenesis of $\mathrm{CD}$ and perhaps the absence of overt disease in genetically predisposed subjects. In China studies in this direction may be of relevance for screening, similarly as in Sweden where investigators have demonstrated by gas-liquid chromatography of short chain fatty acids (SCFA) in fecal samples, that children with screening-detected $\mathrm{CD}$ had a similar fecal SCFA profile to children with symptomatic $\mathrm{CD}$, but this profile differed significantly from the profile in healthy children (51).

If prospective studies of $\mathrm{CD}$ in China in high risk groups turn out to be negative it will have a great significance, not only for planning appropriate measures for public health but also to understand the evolutionary implications in understanding why $\mathrm{CD}$ is the most common food intolerance in the Western world (52).

We hope that our first steps in screening for $\mathrm{CD}$ in China will stimulate others to investigate this disease and stimulate endoscopic studies with biopsy sampling in order to assess and document the clinical relevance of the disease to the public health system in areas of high wheat consumption and the presence of genetic predisposition.

\section{ACKNOWLEDGEMENTS}

This project was supported by State Administration of Traditional Chinese Medicine in P.R. China, No. 2003LHR10.

An abstract of this article was presented at the UEGW 2008 (P0621) and at the First Symposium of the "Sociedad Española de Enfermedad Celiaca" (SEEC) held in Valladolid (Spain) on the 27-28 ${ }^{\text {th }}$ of November 2008.

The authors would like to thank Drs. Xu XP, Lu WM and Xu DH from the Departments of Endocrinology and Gastroenterology in Jiangsu Provincial Hospital of Traditional Chinese Medicine (TCM), for their assistance in recruiting patients; Mr. A. Kromhout from the Section of Immunology of the Department of Pathology, VU University Medical Centre, Amsterdam, the Netherlands for advice and comments in specific serological tests for diagnosis of coeliac disease.

\section{REFERENCES}

1. Van De Wal Y, Kooy Y, Van Veelen P, Vader W, Koning F, Pena S. Coeliac disease: it takes three to tango! Gut 2000; 46(5): 734-7. 
2. Barada K, Bitar A, Mokadem MA, Hashash JG, Green P. Celiac disease in Middle Eastern and North African countries: a new burden? World J Gastroenterol 2010; 16(12): 1449-57.

3. Aktay AN, Lee PC, Kumar V, Parton E, Wyatt DT, Werlin SL. The prevalence and clinical characteristics of celiac disease in juvenile diabetes in Wisconsin. J Pediatr Gastroenterol Nutr 2001; 33(4): 462-5.

4. Barera G, Bianchi C, Calisti L, Cerutti F, Dammacco F, Frezza E, et al. Screening of diabetic children for coeliac disease with antigliadin antibodies and HLA typing. Arch Dis Child 1991; 66(4): 491-4.

5. Carlsson AK, Axelsson IE, Borulf SK, Bredberg AC, Lindberg BA, Sjoberg $\mathrm{KG}$, et al. Prevalence of IgA-antiendomysium and IgAantigliadin autoantibodies at diagnosis of insulin-dependent diabetes mellitus in Swedish children and adolescents. Pediatrics 1999; 103(6 Pt 1): 1248-52.

6. Castano L, Blarduni E, Ortiz L, Núñez J, Bilbao JR, Rica I, et al. Prospective population screening for celiac disease: high prevalence in the first 3 years of life. J Pediatr Gastroenterol Nutr 2004; 39(1): 80-4.

7. Martin-Pagola A, Ortiz-Paranza L, Bilbao JR, de Nanclares GP, Estevez EP, Castaño L, et al. Two-year follow-up of anti-transglutaminase autoantibodies among celiac children on gluten-free diet: comparison of IgG and IgA. Autoimmunity 2007; 40(2): 117-21.

8. Neuhausen SL, Steele L, Ryan S, Mousavi M, Pinto M, Osann KE, et al. Co-occurrence of celiac disease and other autoimmune diseases in celiacs and their first-degree relatives. J Autoimmun 2008; 31(2): $160-5$.

9. Vitoria JC, Castano L, Rica I, Bilbao JR, Arrieta A, García-Masdevall MD. Association of insulin-dependent diabetes mellitus and celiac disease: a study based on serologic markers. J Pediatr Gastroenterol Nutr 1998; 27(1): 47-52.

10. Rensch MJ, Merenich JA, Lieberman M, Long BD, Davis DR, McNally PR. Gluten-sensitive enteropathy in patients with insulin-dependent diabetes mellitus. Ann Intern Med 1996; 124(6): 564-7.

11. Collin P, Salmi J, Hallstrom O, Reunala T, Pasternack A. Autoimmune thyroid disorders and coeliac disease. Eur J Endocrinol 1994; 130(2): 137-40.

12. Lie BA, Sollid LM, Ascher H, Ek J, Akselsen HE, Ronningen KS, et al. A gene telomeric of the HLA class I region is involved in predisposition to both type 1 diabetes and coeliac disease. Tissue Antigens 1999; 54(2): 162-8.

13. Huang HS, Peng JT, She JY, Zhang LP, Chao CC, Liu KH, et al. HLA-encoded susceptibility to insulin-dependent diabetes mellitus is determined by DR and DQ genes as well as their linkage disequilibria in a Chinese population. Hum Immunol 1995; 44(4): 210-9.

14. Rami B, Sumnik Z, Schober E, Waldhor T, Battelino T, Bratanic N, et al. Screening detected celiac disease in children with type 1 diabetes mellitus: effect on the clinical course (a case control study). J Pediatr Gastroenterol Nutr 2005; 41(3): 317-21.

15. Sumnik Z, Cinek O, Bratanic N, Kordonouri O, Kulich M, Roszai B, et al. Risk of celiac disease in children with type 1 diabetes is modified by positivity for HLA-DQB $1 * 02-D Q A 1 * 05$ and TNF -308A. Diabetes Care 2006; 29(4): 858-63.

16. National Institutes of Health Consensus Development Conference Statement on Celiac Disease, June 28-30, 2004. Gastroenterology 2005; 128(4 Supl. 1): S1-9.

17. Green PHR, Stavropoulos SN, Panagi SG, Goldstein SL, McMahon DJ, Absan H, et al. Characteristics of adult celiac disease in the USA: results of a national survey. Am J Gastroenterol 2001; 96(1): 126-31.

18. Sanders DS, Carter MJ, Hurlstone DP, Pearce A, Ward AM, McAlindon ME, et al. Association of adult coeliac disease with irritable bowel syndrome: a case-control study in patients fulfilling ROME II criteria referred to secondary care. Lancet 2001; 358(9292): 1504-8.

19. Ford AC, Chey WD, Talley NJ, Malhotra A, Spiegel BM, Moayyedi $P$. Yield of diagnostic tests for celiac disease in individuals with symptoms suggestive of irritable bowel syndrome: systematic review and meta-analysis. Arch Intern Med 2009; 169(7): 651-8.

20. Kittisupamongkol W. Testing for celiac disease in patients with symptoms of irritable bowel syndrome. JAMA 2009; 301(11): 1126 (author reply).

21. Kotze LM, Brambila Rodrigues AP, Kotze LR, Nisihara RM. A Brazilian experience of the self transglutaminase-based test for celiac disease case finding and diet monitoring. World J Gastroenterol 2009; 15(35): 4423-8.

22. Marine Guillem M, Esteve Comas M. Functional gastrointestinal dis- orders: when and how to exclude celiac disease in a patient with irritable bowel syndrome. Gastroenterol Hepatol 2009; 32(4): 313-4.

23. Jadallah KA, Khader YS. Celiac disease in patients with presumed irritable bowel syndrome: a case-finding study. World J Gastroenterol 2009; 15(42): 5321-5.

24. Green PH. The many faces of celiac disease: clinical presentation of celiac disease in the adult population. Gastroenterology 2005; 128(4 Supl. 1): S74-8

25. Thompson WG, Longstreth GF, Drossman DA, Heaton KW, Irvine EJ, Muller-Lissner SA. Functional bowel disorders and functional abdominal pain. Gut 1999; 45(Supl. 2): II43-7.

26. Longstreth GF. Functional dyspepsia--managing the conundrum. N Engl J Med 2006; 354(8): 791-3.

27. Longstreth GF, Thompson WG, Chey WD, Houghton LA, Mearin F, Spiller RC. Functional bowel disorders. Gastroenterology 2006; 130(5): 1480-91.

28. Dieterich W, Laag E, Schopper H, Volta UD, W, Ferguson A, Gillett $\mathrm{H}$, et al. Autoantibodies to tissue transglutaminase as predictors of celiac disease. Gastroenterology 1998; 115(6): 1317-21.

29. Jiang LL, Zhang BL, Liu YS. Is adult celiac disease really uncommon in Chinese? J Zhejiang Univ Sci B 2009; 10(3): 168-71.

30. Lee GA, Crawford GW, Liu L, Chen X. Plants and people from the Early Neolithic to Shang periods in North China. Proc Natl Acad Sci EE.UU. 2007; 104(3): 1087-92.

31. Han ML. On wheat dissemination in regions south of the Changjiang river (Chinese). Studies in the History of Natural Sciences 1992; 11(4): 353-7.

32. He ZH, Rajaram S, Xin ZY, Huang GZ, editors. A History of wheat breeding in China. México, D.F.: CIMMYT; 2001.

33. Hadithi M, von Blomberg BM, Crusius JB, Bloemena E, Kostense PJ Meijer JW, et al. Accuracy of serologic tests and HLA-DQ typing for diagnosing celiac disease. Ann Intern Med 2007; 147(5): 294-302.

34. Yu RB, Hong X, Ding WL, Tan YF, Wu GL. Polymorphism of the HLA-DQA1 and -DQB1 genes of Han population in Jiangsu Province, China. Chinese Medical Journal 2006; 119(22): 1930-3.

35. Lan Q, Shen M, García-Rossi D, Chanock S, Zheng T, Berndt SI, et al. Genotype frequency and F ST analysis of polymorphisms in immunoregulatory genes in Chinese and Caucasian populations. Immunogenetics 2007; 59(11): 839-52.

36. Dubois PC, Trynka G, Franke L, Hunt KA, Romanos J, Curtotti A, et al. Multiple common variants for celiac disease influencing immune gene expression. Nat Genet 2010; 42(4): 295-302.

37. Zhernakova A, van Diemen CC, Wijmenga C. Detecting shared pathogenesis from the shared genetics of immune-related diseases. Nature Reviews 2009; 10(1): 43-55.

38. Amo Peláez M, Rodríguez Muñoz S, Castellano Tortajada G, Solis Herruzo JA. Ascites and diarrhea. Rev Esp Enferm Dig 2009; 101(10): 712-6.

39. Egea Valenzuela J, Carballo Álvarez F. Celiac disease and pancreatitis: a casual or causal association? Rev Esp Enferm Dig 2008; 100(12): 741-5.

40. Rodrigo L, Álvarez N, Riestra S, de Francisco R, González Bernardo $\mathrm{O}$, García Isidro L, et al. Relapsing acute pancreatitis associated with gluten enteropathy. Clinical, laboratory, and evolutive characteristics in thirty-four patients. Rev Esp Enferm Dig 2008; 100(12): 746-51.

41. Simondi D, Pellicano R, Reggiani S, Pallavicino F, David E, Sguazzini $\mathrm{C}$, et al. A retrospective study on a cohort of patients with lymphocytic colitis. Rev Esp Enferm Dig 2010; 102(6): 381-4.

42. Peña AS, Hadithi M. Antibody testing in coeliac disease. Eur J Intern Med 2010, EJINME1938 DOI:10.1016/j.ejim.2010.06.011

43. Hadithi M, Peña AS. Current methods to diagnose the unresponsive and complicated forms of coeliac disease. Eur J Intern Med 2010; 21: 247-53

44. Rubio-Tapia A, Kyle RA, Kaplan EL, Johnson DR, Page W, Erdtmann $\mathrm{F}$, et al. Increased prevalence and mortality in undiagnosed celiac disease. Gastroenterology 2009; 137(1): 88-93.

45. Ludvigsson JF, Montgomery SM, Ekbom A, Brandt L, Granath F. Small-intestinal histopathology and mortality risk in celiac disease. JAMA 2009; 302(11): 1171-8

46. Rostom A, Murray JA, Kagnoff MF. American Gastroenterological Association (AGA) Institute technical review on the diagnosis and management of celiac disease. Gastroenterology 2006; 131(6): 19812002 
47. Corazza GR, Villanacci V, Zambelli C, Milione M, Luinetti O, Vindigni $\mathrm{C}$, et al. Comparison of the interobserver reproducibility with different histologic criteria used in celiac disease. Clin Gastroenterol Hepatol 2007; 5(7): 838-43.

48. Collado MC, Donat E, Ribes-Koninckx C, Calabuig M, Sanz Y. Imbalances in faecal and duodenal Bifidobacterium species composition in active and non-active coeliac disease. BMC Microbiology 2008; 8: 232.

49. De Palma G, Nadal I, Medina M, Donat E, Ribes-Koninckx C, Calabuig $\mathrm{M}$, et al. Intestinal dysbiosis and reduced immunoglobulincoated bacteria associated with coeliac disease in children. BMC Microbiology 2010; 10: 63.
50. Nadal I, Donat E, Ribes-Koninckx C, Calabuig M, Sanz Y. Imbalance in the composition of the duodenal microbiota of children with coeliac disease. J Med Microbiol 2007; 56(Pt 12): 1669-74.

51. Tjellstrom B, Stenhammar L, Hogberg L, Falth-Magnusson K, Magnusson KE, Midtvedt T, et al. Screening-detected and symptomatic untreated celiac children show similar gut microflora-associated characteristics. Scand J Gastroenterol; 2010.

52. Zhernakova A, Elbers CC, Ferwerda B, Romanos J, Trynka G, Dubois PC, et al. Evolutionary and funcional analysis of celiac risk loci reveals $\mathrm{SH} 2 \mathrm{~B} 3$ as a protective factor against bacterial infection American Journal of Human Genetics 2010; 86(6): 970-7. 